\title{
Preventing Maladministration on Issuing Mining License (a Case Study in Southeast Sulawesi, Indonesia)
}

\author{
Oheo K.Haris ${ }^{1}$, Rizal Muchtasar and Sahbudin ${ }^{2}$, \\ 1 Lecturer at Department of Administrative Penal Law, Faculty of Law, University of Halu Oleo, \\ Southeast Sulawesi, Indonesia. \\ 2 Lecturer at Department of Administrative Law, Faculty of Law, University of Halu Oleo, \\ Southeast Sulawesi, Indonesia.
}

\begin{abstract}
This study is aimed at exploring appropriate method in embodying and applying the principle of good governance in managing strategic resources, i.e. in issuing mining license. This effort is important to prevent maladministration, corruption, and the deterioration of environmental quality that may block the sustainable development. This maladministration in issuing mining license has created complexity and overlapped administrative decisions, either at the vertical or horizontal. At the vertical level the tension, conflicted, and overlapped administrative decision could be seen between central and local government, whereas at horizontal level, conflicted decision could be seen at sectorial department. For that reason, this work offers an appropriate method in integrating and embodying the principle of good governance, such as transparency, carefulness, and proportionality in issuing mining license. The application of this method may create a holistic and integrated policy in managing and optimizing collective strategic resources for the greatest benefit for greatest number of people. Keyword: Maladministration and Issuing Mining License.
\end{abstract}

\section{Introduction and Literature review}

Natural resources, in Indonesia, have broadly become for a national wealth and prosperity[1] which consists of oil, gas, and mining that deploys into a landmass of the country. However, the resources, in Southeast Sulawesi, has significantly underpinned sustainable development and created social benefit[2]. According to Article 1 point 6 Laws 23 of 2014[3], concerning the Local Government, the Administrative body was hugely given a power in order to manage public service and to handle a variety of resource potential including mining resources. Besides, the basic provision and procedural mining license (refers as IUP) has been also promulgated through Law Number 4 of 2009

*Corresponding Author : oheo.haris@uho.ac.id 
concerning Mineral and Coal Mining. At the essence, Administrative body created administrative decision which required managing and seeking potential minerals and coal in independent, reliable, transparent, competitive, efficient and environmentally sound manners to sustainably assure national development[4].

Due to issuing mining license, discretion occasionally committed maladministration, corruption, and the deterioration of environmental quality that may block the sustainable development. This maladministration in issuing mining license has created complexity and overlap administrative decisions, either on the vertical or horizontal. At the vertical level the tension, conflicted, and overlapped administrative decision could be seen between central and local government, whereas at horizontal level, conflicted decision could be seen at sectorial department. For that reason, in order to determine the boundaries of scope and precise roadmap, this work offers an appropriate method in integrating and embodying the principle of good governance, such as transparency, carefulness, and proportionality in issuing mining license.

\subsection{The Philosophy Base of Mining Business License Issuance}

This section discusses government's Legal Power based on the legal and justice perspective. Government's action to act on the principle of state of law is primarily related to legal protection of basic rights. Nevertheless, constitution legitimation for government can be perused in Article 1 of Indonesian Constitution 1945 that functions as principle of state of law, and Article 33 of Indonesian Constitution 1945 that functions as the right of state control (HPN) as well as principle of welfare state. Ratio Legis (legal reasoning) in those articles suggests that the state goal is creating the greatest benefit of the people.

The explanation above converges with the idea and concept in the Preamble of Indonesian Constitution 1945, which is the essence of the fifth principle of Pancasila (the philosophical basis of human rights in Indonesia). Bagir Manan unraveled the definition of HPN in the context of Indonesian constitution based on the stipulation in Indonesian Constitution 1945 as follows: (1) Controlling in the form of state ownership, which means that the state through government is the only one that has Legal Power to decide Legal Power right over resources, including land, waters, and any natural riches contained therein; (2) Regulating and overseeing exercise and utilization; (3) Capital assistance in the form of state companies for certain businesses.

The philosophy perspectives of Lon L. Fuller, Anthony D'Amato, and Richard B. Howarth have a vision of similarity of justice, but they are different in implementation. The Lon F. Fuller's explication puts more emphasis on justice recognition by way of injustice; it is popularly known as injustice. On the other hand, the teaching of Anthony D'Amato highlighted the internal notion of justice. This idea is popular in practitioner groups and lawyers. The theoretical approach of Anthony D'Amato is the approach of recognizing justice and justice and equality. In a similar vein, Richard B.Howarth in his abstract focused on non-renewable resources. In his concept of intergeneration justice, a chain of obligations inherent in intergeneration justice, this is the existence of the current generation's life and future generation. Furthermore, in his argumentation, with the preparation of natural resources availability, the future generation will look different compared to heritage from one generation to another generation without significant difference. The purpose is to ensure that natural resources, including mining, do not run out for the future generation, and to achieve the goal it is necessary to have an intergeneration justice-based policy in mining management. The description implies that justice in the context of natural riches in Indonesia is relevant if it adopts the thought of the three legal experts above.

The aforementioned principle definitions underscore that mining management is the foundation or compass that guides not only the government's actions, but also people's in a 
larger scope. These principles are automatically parallel to good governance principles. Sudikno Mertokusumo asserted that law or law principle is not a concrete legal regulation, but it is basic thoughts that are general or the background of concrete regulation inherent in every legal system. The legal system later evolves into laws and judge's decisions, which are positive laws, or what can be found by scrutinizing general characteristics in those concrete regulations. The function of legal studies is to discover legal principles in positive law.

\subsection{Norm Formulation of Government's Legal Power in the Issuance of Mining Business License}

The function and Legal Power of government to issue IUP can be studied through Legal Power. The term "legal power" in Dutch is "bevoegheid" and "gezag" in German. In English, the term "legal power" is understood as "competence", which means ability, capability, and qualification. Legal power is a term that is related to authority, power, and force. Such legal power is legitimate if it is performed according to law and preferentially owned by the state that has right to demand compliance. The scope of the law is within the public sphere.

According to its function and legal power, the implementation of IUP issuance is the legal power of authorized public officers; referring to the law Article 22 paragraph (3) Central Government Regulation 23 of 2010 on Implementation of Mining Business Operations that was amended by Central Government Regulation 24 of 2012. The regulation stipulates several points: (1) IUP that is stipulated in Article 7 letter b consists of (a) Exploration IUP and (b) Production Operation IUP; (2) Exploration IUP consists of (a) metal minerals, (b) coal, (c) nonmetal minerals, and/or (d) rocks. According to Article (3), the operation IUP comprises: (a) metal minerals, (b) coal, (c) nonmetal minerals, and/or (d) rocks. Mining supervision is stipulated in Presidential Instruction 1 of 2004 on the Implementation and Supervision of Coal Mining Business Activities. With the function and Legal Power of authorized officials, it is obvious that the position of the officials includes the administrative position of government in mining management.

The function and legal power to issue mining business permit are the task and responsibility of authorized officials in accordance with administrative law. Regarding the responsibility of authorized officials in mining management, the officials need to respond to a system and administrative mechanism in the body of government organ. Philipus M. Hadjon explained that the legality of a letter or decision including mining business permit issuance should be supported with the following matters: (1) Existence of legal power, (2) Correct procedure, and (3) Correct substance. The procedural defect is a defect that is present in a series of administration process phases. This defect has potential to become a criminal act if there is maladministration in the defect. Maladministration can become a criminal act if there is collusion or bribery found as regulated in Article 21 Laws 28 of 1999 on the State Officials Who is Clean from Collusion, Corruption, and Nepotism. In administration, if procedural defects like maladministration happen, the procedure can be repeated. Thus, there is no forgery procedure, and it does not make an administrative decision become void.

Source of legal power in IUP issuance can be elucidated from the points of view of several experts. Legal power, according to Tatiek Sri Djatmiati, is a power owned by an administrative body or authorized officials in conducting real acts, enacting regulation, or issuing a decision that is based on attribution, delegation, or mandate. Attribution refers to original legal power according to the stipulation of state law. Delegation emphasizes a transfer of legal power to another government body, while mandate does not entail any transfer in terms of delegation of legal power. The mandated officer acts on behalf of 
mandatory (the one who gives mandate). In mandate transfer, the officer that gives mandate appoints another officer to act on his/her behalf.

With regard to legal power, Philipus M. Hadjon emphasized that the legal power term in administrative law literature means gave free rein to. In real practice, the word 'policy' (beleidregel) is more familiar. As a comparison, a term that can be used in various systems of administrative law is coined. From the explanation, the term 'legal power' shall be introduced according to legal power essence with the references as follows: discretionary power (English administrative law), ermessen (not "freies ermessen", German administrative law), discretionarie bevoegheden (Dutch administrative law), vrij bevoegdheid. According to the essence of those terms and concepts, the term 'legal power' is used in Draft Law on the Government Administrative.

The nature of the term 'legal power' is used as the opposite of rule-bound legal power (gebonden bevoegdheid). Based on its essence, there are two choices to carry out the governmental act. The choice is attributed to: (a) Norm formula, such as-suspect can be detained...-in certain condition....-shall...-should..., and for the public interest ....and others.

(b) The factual condition, such as -disaster and emergency situation and etc.

Maladministration that carries criminal offense implication can be abuse of legal power in mining business permit issuance that can result in total loss of financial, corruption from the mining profits, bribe from mining businessmen, and gratification like facilities given by mining businessmen with intention to obtain permit issuance without having to embark on the right mechanism and procedure of obtaining mining business permit. Philipus M. Hadjon contends that maladministration does not only bear administrative and civil responsibilities, but also criminal responsibilities, for example, bribery, gratification, collusion, corruption, and many others.

Addressing the misuse of legal power, Nur Basuki Winarno [5] in his book entitled "Penyalagunaan Wewenang Dalam Pengeolaan Keuangan Negara" argued that an act that has a constituent of "violating the law" is the "genus", while the constituent of "misuse of power" is the "species". Then, the growing number of maladministration practices, especially the ones with criminal offense implication in permit issuance in the mining sector, can be found in several regions.

In general, the public understands the definition of maladministration as an administrative fault that is not important (trivial matters). If the reference is based on the Article 1 paragraph 3 Laws 37 of 2008 on the Ombudsman of Republic of Indonesia (ORI), maladministration definition is very wide and encompasses various matters that can cause material and immaterial losses and injustice condition where the citizens' rights are jeopardized.

Sir Edmund Comton cited by Tatiek Sri Djatmiati, in the first British Parliamentary Commissioner for administration or Ombudsman, affirms this condition by stating:

"Nobody can define maladministration in plain terms. It may be difficult to define, but most of us believe that we could recognize an example of it if we saw it. We can describe it by examples. We know what it is, but we are quite ready to admit that we might find ourselves in disagreement with other people about whether or not a particular case was an example of maladministration. We would admit also that there might be a vague and unclear boundary surrounding the areas of maladministration.

In the context of law in Indonesia, the Article 1 paragraph 3 Laws 37 of 2008 defines maladministration as follows:

Maladministration is the behavior or act against the law, exceeding the Legal Power, using power for purposes other than those which become the objective of such power, including ignorance or negligence of legal obligation in administering public services such as conducted by the State Officials and 
Public Officials which affect damage to the community and/or individual, both materially and immaterially.

One of the weaknesses of ORI's role is that it does not have executorial power because it is only deemed as a recommendation. This can be seen in Article 351 Laws 23 of 2014. Generally, it is stipulated in paragraph (5) The head area that does not implement the recommendations of the Ombudsman as a follow up complaints referred to in paragraph (4) shall be liable to a special coaching deepening field of governance implemented by the Ministry as well as the duties and legal power held by the deputy head of the regional or appointed official. If it is examined from a legal perspective, it can be inferred that maladministration is the source of the fatalistic act over the legal acts of authorized officials that certainly have legal consequences. Therefore, maladministration conducted by authorized officials can only be deemed as "dead rules" that are not legal problem-solving.

Maladministration is administration infringement that has criminal offense consequence like abuse of Legal Power that is criminally accountable. The legal concept on juridical defects can be used as guidance. Philipus M. Hadjon explicates the scope of government acts consisting of legal power, procedure, and substance. In substance level, failure of the fulfillment of those three legal components leads to a juridical defect of a government act. The legal framework on this juridical defect, according to administrative law, is used as the basic testing (toetsingsgronden) of government act legality and state administrative law decision (beschicking).

\section{Objective of the study}

The purpose of this research is to examine the causal factors of maladministration in managing and issuing mining license. The application of this method may create a holistic and integrated policy in managing and optimizing collective strategic resources for the greatest benefit for greatest number of people.

\section{Methodology}

In the present study, there are some legal issues approaches such as: philosophy of mining business permit issuance, norm formulation of government's legal power to issue mining business permit, and government's legal power to issue mining business permit that carries criminal offense consequence. The present study aims to reveal the philosophy of mining business permit issuance. It also attempts to formulate norm formulation of government's legal power to issue mining business permit. Finally, the present study intends to find the qualification of government's legal power to issue mining business permit that has criminal offense consequence. The method used in the present study is divided into type of study and problem approach. Type of study refers to legal research. The legal study characteristic is to discover pragmatic truth where its truth is based on the congruence between the examined truth and imposed rules. Peter Mahmud Marzuki stated that legal research is a process to find out the rule of law, law principles, and law doctrines in order to solve an existing legal problem. It is in line with the prescriptive character of legal studies. Mahmud Marzuki said that problem approach, according to the theory of Peter, is a study using several approaches as a whole unity, which is statute approach, case approach, and conceptual approach. 


\section{Discussion}

\subsection{Principle of Transparency}

The principle of transparency towards issuing mining license has become prerequisite of the administrative decision. It is asserted that the government must have a strong equitable commitment. Not only transparency work should be engaged, but also the principle of participation that is able to be accurately accessed with sufficient and adequate information. According to Addink mentioned[6] that;

The government should be accountable for its actions and this is difficult if it has a "monopoly" over the available information. Individual citizens should be able to know the information held about them in order to check its correctness and the use to which it is put. It is hoped furthermore that public disclosure of information will improve decision-making. (P. Craig, EU Administrative Law, 2006, p.350).

In order to be able to integrate and embody good governance compliance, the local government initiative takes all of the citizen into account mainly in the affirmative of one consent between government and local people i.e. consensus and openness. This openness, according to Addink, is necessary for the two forms of democracy: both in direct and in representative democracies, openness is always needed. In general, it can be distinguished by the following three types of transparency: transparency of meetings, transparency of the administration's actions, and transparency in access to public information.

Concerning the rights of social basic was whether considerably emphasized as fundamental rights or as the human right. This affirmation has argued by Bradley that quoted by Tatiek Sri Djatmiati[7] who mentioned that the first task is to determine what is meant by human rights: there is a great deal of terminological inconsistency in this area, with a number of terms frequently used-human rights, civil liberties, fundamental rightsoften referring the same thing. Thus, it can be considered as part of creating a holistic and integrated policy in managing and optimizing collective strategic resources for the greatest benefit for the greatest number of people.

In the founded case can be described that local government distastefully issued a mining license to some mining company without officially inform the indigenous people. The case in point is Number 02/G/2010/PTUN-Kdi (Administrative Court), in which the administrator decision (as defendant) has issued the license with Number 407, on 31 December 2008, concerning Approval Reservation of Mining Area of P.T Panca Logam Nusantara (mining company), to operate mining activities that located (2000 hectares) in the district of North Rarowatu, Regency of Bombana, and Province of Southeast Sulawesi. In consequence of issuing mining license, the area of exploration and exploitation had been long time occupied by the mining company.

In the case of a lawsuit, the defendant revealed some infractions that are; (a) Laws 23 of 2014, which states, "The managed land, which runs by the company, must belong to the state land. And the Regent represents the State". This meant, the regent has discretion in issuing mining license. In addition, the defendant has evidence such a copy of an official letter from Indigenous Leader.

Otherwise, indigenous people (Plaintiff), however, apparently claimed that mining area belongs to them. Accordingly, it is clear enough by showing several pieces of evidence, not only against the principle of transparency, but also paradoxically went against Article 3, Laws 14 of 2008, The Openness of Public Information which says (a) to guarantee the citizen rights that should have a received information in policy-making process, including the reason of a made policy; (b) to encourage public participation in policy making-process; (c) to enhance and involve participation for all of citizen actively in policy making-process 
and manage a better-public service; (d) to create a good governmental administration, that consisted of transparency, effectiveness, efficiency, liability, responsibility, as well as accountability. Another evidence was Article 8, Laws 4 of 2009, Mineral and Coal Mining, which stated to grant Mining Permits and Small-Scale Mining Permits, direct, settle, communal conflicts, and supervise production operation mining business, of which the activities are located in districts or cities and or the territorial sea up to 4 (four) miles;

Due to final adjudication, the judge has pushed away from the claim for the plaintiff (indigenous people) and for at least declared wholly unacceptable (Niet Ontvankelijke Verklaard). Whereas considering the rationale, the judge's opinion (ratio decidendi), decided that the plaintiff was not able to prove the rights of Communal Land. It could be asserted; whether indigenous people have been a long time lived in the mining area. This argument is based on Provision of the Minister of Agrarian/ Head of National Land Agency Number 5 of 1999, Dispute Resolution on Communal Land Rights of Indigenous People, in particular, article 2, paragraph (2) and article 5, paragraph (2). On other hands, the verdict declared that Regent Decree (object of a lawsuit) was lawfully accepted.

Those statements above can be described that the Regent has a failure to comply the principle of governance, particularly the principle of transparency. Furthermore, the Regent has also ignored the rights to heard and disregard the freedom of information (FOI). This FOI actually has a relationship with the human right context in which the people have the rights to access any kind of information. This argument, moreover, has had agreed by Patrick Birkinshaw who worked for paper "Transparency as a Human Right, Transparency the Key to Better Governance"

\subsection{Principle of Carefulness}

This principle is required a careful act in order to avoid disadvantages of the public. However, not only common sense is expected, but administrator also should have a common ground which regards the public needs such as achieving an appropriate treatment, a quick response in handling the complaint, and a suitable in deriving some information particularly policy-making process.

Kuntjoro Purbopranoto pointed out the principle of carefulness, prior to forming policy, the administrator should primarily come up with research that is relevant to all the facts particularly in the hearing, considering as well as legal consequences and subsequently put into their policy. Addink argued that in the principle of carefulness the substantive and the formal part. Substantive carefulness means a careful balance of interest. In formal carefulness steps in the procedure of ordering are distinguished as follows: a. treatment, b. researching, c. consultation, d. publication[8].

Wairocana has divide upon this principle into four divisions that separated in the following way[9];

1. Preparing for carefulness

According to Brouwer, that quoted by Wairocana, showed this principle as mentioned in article 3 point 2 Awb (Algemene wet bestuur). He, furthermore, pointed out that when preparing an order and administrative Legal Power shall gather the necessary information concerning the relevant facts and interests to be considered.

2. Investigation

In this stage, for example, in order to execute such orderliness, the Legal Power shall look in more detail the aimed object, particularly in juridical aspects. It is crucial to note whether the offender has fulfilled some requirements of rules or has to be taken over by agencies.

3. Carefulness Hearing 
This principle required that for those who have an interest must be heard first before facing in a certain decision-making process. Due to an administrative view, this principle actually has two meanings; the Legal Power's decision should be the boundaries precisely, whereas, regarding public services, the Legal Power must know some mistakes. The famous scholar such as J.G. Brouwer and AE Schilder, on their research "A Survey of Dutch Administrative Law", argued that the duty to hear means on the one hand that there is a certain burden for the administrative Legal Power. On the other hand, the administration also receives some benefit from it. If the administration does not obtain further information from the citizen, then chances are that a wrong decision will come up.

4. Carefulness Publication

J.G Brouwer and A.E.Schilder, quoted by Wairocana, viewed that a fundamental requirement for law and treaties in force in publication. It can be specifically mentioned that publication was concerned with rules and regulation. This opinion based on Article 38 of Dutch Constitution that stressed on; the publication and entry into force of the act of parliament shall be regulated by of act of parliament. They shall not enter into force before they have been published. What is more, this Act seemingly is the same with Laws 12 of 2011, in which it has binding with a certain date, except it established into another rule.

In the following case, Number 01/G/2010/PTUN-KDI (Administrative Court), can be described as the party of a lawsuit between a number of people (Plaintiff) and Regent and Mining Company (Defendant I and II). In the requested claim (Petitum) was to lift out and to assert an illegal decree (Number 340a/04/11/2008) concerning Exploration Mining Permits and Production Operation Mining Permits.

In the case of a lawsuit, the Regent, in issuing mining license, has declared the Decree without doing some research towards mining location such as no feasibility study, no environmental analysis, and no publication. In fact, the Regent Decree paradoxically went against Article 3 and 20 (1) Laws 5 of 1960, Provisional Basic of Agrarian and Article 2 and 4 (1, a), Minister Regulation of Agriculture of the National Land Agency Number 5 of 1999, concerning Guidelines for Communal Settlement Issues of Indigenous Peoples Rights, Article 5 paragraph (3). In addition, it was also in contradiction Law Number 41 of 1999, concerning Forestry, Article 39 paragraph (1) and (2) letter 1 and q (in respect of dispute settlement and recognizing the existence of communal right), and Article 39 (1) and (2).

Although the administrative bodies have shown several pieces of evidence, they were obviously rejected by Judges that obviously considered that defendant' objections were the unreasonable arguments. Therefore, in the verdict stated to accept the plaintiff appeal, while the judge refused the defendant's objection.

\subsection{Principle of Proportionality}

The principle of good governance, in the context of Indonesian literature, generally refers to Netherlands administrative law. Grouping of those principles was composed as follow;

1) The group of governing principles that has a formal characteristic in dealing with the policy-making process.

2) The group of governing principles that has a formal characteristic in relating to motivation due to issuing-decision.

3) General principles of good government that have a material in connection with the content of the decision [10]. 
Other scholars such as van Vusg has already put in across this principle by means of the proportionality test. The principle to use of discretionary powers, and can be used to analyze the balancing of interests in the following way;

1) Firstly, aim to be reached must be determined. This aim must be legitimated and must be attainable by the exercise of powers, prescribed the law.

2) Secondly, the legal instruments which meant to reach the suitable and necessary goals.

While the others, but the whole is less drastic available instruments, these instruments shall be applied.

3) Thirdly, it should be proper to balance the disadvantages of measures for individuals.

According to the Laws 28 of 1999, concerning the Governance Clean and Free of Corruption Collusion and Nepotism, mentioned on article 3, point (5), the principle of proportionality is the principle that completely gave a balance between rights and obligations. This matter was strengthened by Addink stated that the principle of proportionality has to be used in the context of administrative sanctions (individual and general), and more broadly in the sense of a right balance between means and aims[11].

Administrative bodies, in issuing mining license, shall have to regarded principle of proportionality. Absolutely, this principle shall be paid attention that the undertaken action must be proportionate to its objectives, especially concern to protect the citizen and the premise that regulatory must be suitable to achieve its goal[12].

According to Eric Engle[13], this historical overview aims to show that proportionality as the principle of law arose out the Aristotelian concept of justice. This general theoretical fact partly explained the worldwide success of the concept, since it has deep, global, common roots. The principle, as result, became instantiated into law.

In the following case, it can be expressed by the parties between mining company (Plaintiff) and the Regent (Defendant) by means of the registered case; Number 3/G.TUN/2011/PTUN-Kdi (Administrative Court). The plaintiff brought the lawsuit to the court by claiming that the regent has issued the decree of a mining license, Number 25/2001/10-01-20011, and it was an illegal decree and must be cancelled. Since it was contradictorily with article 119 point a, b, and c, Law Number 4 of 2009, Mining Mineral and Coals which defines Mining Permits or Special Mining Permits shall be revoked by the Minister, governors, regents, and mayors within their Legal Power if:

a. Mining license holders or Special Mining Permit holders fail to meet obligations as stated in the Mining Permit or Special Mining Permit as well as laws and regulations;

b. Mining license holders or Special Mining Permit holders have perpetrated criminal acts as intended by this Law, or

c. Mining license holders or Special Mining Permit holders are declared bankrupt.

In another lawsuit, the regent decisively made overlapping administrative decisions. They claimed the regent committed arbitrariness and a collusive agreement which refers to the Governor Decree, Number 540/23, concerning an overlapping zone of Special Mining License, 04th January 2011. Therefore, the decree was manifestly contrary to the principle of proportionality in which the defendant made an imbalance act on issuing mining license without legitimated expectations, consistency and advice, courtesy, notification of the decision, data protection, and responses to requests for information, even the two institutions went into cahoots causing abuse of power[15].

\section{Conclusion}

Finally, aforementioned three principles above, as the root causal factors of maladministration, and can be concluded that due to discretionary power particularly on issuing mining license, discretion must be first identified through its characteristics that consisting of formal Legal Power, an existing procedure, and task content. Those 
characteristics, however, should be examined whether plaintiffs have the interest to suit as required on article 53 (1) Law Number 9 of 2004, on Administrative Court. Furthermore, in the opinion of Indroharto , the understanding of "interest" has three meaning those are; (a) an interest which interpreted as value protected by the law, (b) the aims in order to achieve a process, which meant, the persons involved must have purpose a lawsuit to the court. Last, not least, the interest here should have adequate disclosure and appropriable reasons as well as bringing legal base. Theoretically mentioned on legal procedures that was wellknown: "Point d'interet, point d'action" which means "No legal standing, no lawsuit".

\section{References}

1. Hadjon, M. Philipus, Legal Protection for Citizen in Indonesia (Perlindungan Hukum Bagi Rakyat di Indonesia), (Peradaban, Surabaya, 2007).

2. As mentioned on The 1945 Constitution of the Republic of Indonesia, chapter XIV, article 33. As amended by the First to fourth Amendment. It is mentioned on paragraph three "The land, the waters and the natural resources within shall be under the powers of the State and shall be used to the greatest benefit of the people."

3. Law Number 23 of 2014, the Local Government, State Gazette of the Republic of Indonesia of 2014 Number 244. Supplement to State Gazetteer of the Republic of Indonesia Number 5587.

4. Law Number 4 of 2009, Mineral and Coal Mining, State Gazette of the Republic of Indonesia Number 4 of 2009. Supplement to State Gazette of the Republic of Indonesia Number 4959.

5. Ibid,

6. N. B. Winarno, Abuse of Power and Criminal Act of Corruption (Penyalahgunaan Wewenang dan Tindak Pidana Korupsi), (Laksbang Mediatama, Yogyakarta, 2009).

7. G.H. Addink et al, Human Rights and Good Governance, ISBN/EAN: 978-90-3935490-2, (Universiteit Utrecht, Netherlands, 2010).

8. T. S. Djatmiati, Public Services and Corruption Crime, Administrative Law and Criminal act of Corruption, (Published by Gadjah Mada University Press, Yogyakarta, 2011).

9. Op.Cit, G.H. Addink.

10. I. G. N. Wairocana, Good Governance in the Law Enforcement Context, Administrative Law, and Good Governance. Written by Philipus M.Hadjon, et.al. (Published by University of Trisakti, Jakarta, 2010).

11. S. Nugraha et.al, Administrative Law, Center for Law and Good Governance Studies (CLGS), (FH UI, Indonesia, 2007).

12. Loc.Cit, Addink.

13. T. Tridimas, Proportionality in Community Law: Searching for the Appropriate Standard of Scruntiny. The Principle of Proportionality in the Laws of Europe, edited by evelyn ellis, (Hart Publishing, 2000).

14. E. Engle, The History of General Principle of Proportionality: an Overview, Journal, (University of Tilburg, and University of Utrech, Netherlands, 1998).

15. Loc.Cit, Addink.

16. Indroharto, Understanding the Indonesian Administrative Court, Published by Aditya Ltd, Jakarta, 2009, p. 37. (Usaha Memahami Undang-Undang tentang Peradilan Tata Usaha Negara, Buku II, Beracara di PTUN, Aditya, Jakarta, 2009).

17. The 1945 Constitution of the Republic of Indonesia.

18. Laws 41 of 1999, Concerning Forestry, State Gazette of the Republic of Indonesia of 1999 Number 167. Supplement to State Gazetteer of the Republic of Indonesia Number 3888. 
19. Laws 14 of 2008, the Openness of Public Information, State Gazette of the Republic of Indonesia of 2008 Number 61. Supplement to State Gazette of the Republic of Indonesia Number 4846.

20. Laws 4 of 2009, Mineral and Coal Mining, State Gazette of the Republic of Indonesia Number 4 of 2009. Supplement to State Gazette of the Republic of Indonesia Number 4959.

21. Laws 23 of 2014, the Local Government, State Gazette of the Republic of Indonesia of 2014 Number 244. Supplement to State Gazetteer of the Republic of Indonesia Number 5587.

22. Central Government Regulation Number 23 of 2010 on Implementation of Mining Business Operations.

23. Minister of Energy and Mineral Regulation Number 7 of 2012.

24. Minister of Energy and Mineral Regulation Number 17 of 2010.

25. Minister of Energy and Mineral Regulation Number 28 of 2009.

26. Minister of Energy and Mineral Regulation Number 34 of 2009.

27. Minister of Agrarian/ Head of National Land Agency Number 5 of 1999, Dispute Resolution on Communal Land Rights of Indigenous People

28. Decree of Governor Number 435, $26^{\text {th }}$ July 2010.

29. Decree of Regent Number 407, $31^{\text {th }}$ December 2008.

30. Decree of Regent Number 342, $5^{\text {th }}$ November 2008. 